\title{
Research Notes
}

\section{Pakistan and West Asia}

\author{
Imtiaz H. Bokhari \\ Institute of Strategic Studies, Islamabad
}

State to state relations between Pakistan and Southwest Asian states date back to the birth of Pakistan in 1947, but the ideological bonds are much older. In 1946, it was late king (then prince) Faisal who chaperoned the Pakistan Movement delegation headed by Mr. Isphahani that visited the United Nations and got sympathetic ears to its pleas. ${ }^{1}$ Again, the Saudi king was the first head of state to felicitate Mohammad Ali Jinnah after learning of the Viceroy's decision to grant independence to Pakistan and India. Equally warm and sincere support came from Iran.

\section{Pakistan and West Asia: Evolution of Relations}

Immediately on achieving independence, Pakistan displayed notable enthusiasm in advocating the cause of Islam and Islamic states but soon learnt to be more patient. Pakistan's call for Islamic unity was seen by the Arabs as a move to stifle nascent Arab nationalism at the instigation of the West. These developments corresponded to the early 50s when Pakistan, under intense threat from India, signed the Mutual Defense Aid pact with the United States $^{2}$ and became a suspect in the eyes of the Arabs who thought of Pakistan as an instrument of the West. Pakistan's joining of the Baghdad Pact in 1954 along with Iraq was also interpreted by the Arab nationalist leaders as a neocolonial move to divide the Arab world. Saudis even called it a stab in the heart of the Arab and Muslim states. ${ }^{3}$ In 1956, Indian Prime Minister Jawahar Lal Nehru's warm welcome in Saudi Arabia followed by the Suez Crisis put Pakistan's relations with those important Islamic states at their lowest level. During that period the Arabs viewed the region mostly in the Arab and non-

Dawn, Karachi, Saudi Supplement 1977, p. 3.

Mujahid-al-Sharif, Quaid-e-Azam and World Muslim Unity, Pakistan Horizon, Vol. 34, No. 1,1981 , p. 27

3 Burke, S.M., Pakistan Foreign Policy, Oxford University Press, Karachi, 1973, p. 204. 
Arab context. Pakistan's lack of dexterity in handling these situations and its failure to convince the Arabs that neither was its alliance with the United States anti-Arab nor did it seek leakership of the Islamic world, also played a part in its low standing with these states.

By the mid-50s Pakistan's relations with Iran and Turkey (two non-Arab states) had matured. But relations with Afghanistan remained indifferent, to say the least. It is worth recalling that Afghanistan was the only country which opposed Pakistan's entry to the United Nations.

By the end of the 50s, the misreading of Pakistan's reasons for championing Islamic unity, which essentially emanated from its sense of insecurity, was yielding ground to greater understanding of its motives, particularly in Saudi Arabia, whose relations with Egypt were getting estranged. The polarization of the radical and conservative Arab states became complete in September 1962 with the eruption of civil war in Yemen. ${ }^{4}$ Saudi Arabia sought and was provided arms by Pakistan ${ }^{5}$ (and Iran). So, by the early 60s Pakistan's relations withe Iran and the Arabian Peninsular states had taken on security dimensions. During its war with India in 1965, Pakistan received strong support from the Southwest Asian states and even Afghanistan assured Pakistan not to worry about its western frontiers. This deepend mutual commitments and Pakistan signed a bilateral defence agreement with Saudi Arabia in 1967. It was already tied with Iran under CENTO-a successor to the Baghdad Pact.

In spite of this growing relationship, Pakistan's peculiar geographic situation, with a western and an eastern wing, kept it firmly tied to South and even to Southeast Asia. it was only after 1971, when its Eastern wing became Bangladesh, that Islamic unity became the principal instrument of Pakistan's foreign policy and it opted out of SEATO and downplayed its South Asian linkage as far as possible. Pakistan also provided skilled and semi-skilled manpower in large numbers to Southwest Asian states to meet the needs of their growing developmental plans following the oil boom. During the rest of the decade of the 70s, Pakistan's role in the region was substantially enlarged in almost all fields. Until the end of the decade Pakistan's relations with the rest of Southwest Asia were mostly conducted on a bilateral basis but still did not include a common security perception.

\section{Pakistan's Regional Identity}

At this stage, it would be useful to analyse Pakistan's view of its regional identity as this substantially affects decision-making in Islamabad. In con-

Dawisha, Adeed, Saudi Arabia's Search for Security, Adelphi Paper, No. 158, 1155, London, 1980 , p. 3.

Ibid., p. 3. 
fining Pakistan to South Asia alone, history and tradition play a greater role than geography and politics. Pakistan writes Leo Rose, and I quote "occupies a highly strategic position between South, Southwest, and Central Asia, and thus belongs to all three regions." 6 unquote Pakistan, by the sheer weight of recent events, is obliged to play a major role in Southwest Asia in the interest of its own security.

In the present geo-strategic environment, Pakistan's stability and security is tied both to Southwest and South Asia. Less than 200 miles, (almost the same distance as the Gulf proper at its widest), separate Pakistan from the Arabian Peninsula. Any presence on the coast of Pakistan which is hostile to the interests of Southwest Asian states would place them in a position of grave disadvantage. It was in this context that President Zia ul-Haq had said that Pakistan "constitutes the back door to the Gulf and direct access to the Indian Ocean."

Similarly any hostile presence either in Iran or on the Arabian Peninsula would very adversely affect the security calculus of Pakistan. In fact, Pakistan would be surrounded by adversaries from all sides which would leave it no room for political manoeuver. Therefore, Pakistan's relations with Southwest Asian states are based on a mutuality of interests that promise to endure.

\section{Commonality of Threat Perception}

Since the beginning of the $80 \mathrm{~s}$, the most significant of their mutual interests is a common perception of Soviet threat. Though Russian obsession with southward expansion dates back to over two centuries, it is not the antiquity but its durability which is a source of grave concern to the regional states. During the Second World War the Soviet Union declared that "its territorial aspirations centre, South of the national territory of the Soviet Union in the direction of the Indian Ocean." In the absence of an explicitly declared intention, many academics have discounted this warm water theory but there is little evidence to suggest that the Soviets are no longer interested in securing such an important advantage, particularly if it were to come cheaply.

The regional states apreciate that the Soviet Union has a major and abiding interest in Southwest Asia as, apart from oil, its geopolitical centrality provides it with a perfect base for projecting power in the direction of the Indian subcontinent, Africa or both, and checking that of its adversary. In Saudi opinion the Soviet move into Afghanistan has Gulf oil as its objective, but at the same time a direct threat could precipitate a superpower confrontation.

Leo E. Rose, "Pakistan's Role and Interests in South and Southwest," Asian Affairs, Vol.

9, No. 1, September/October 1981, p. 50.

7 J. C. Hurewitz, Diplomacy in the Near and Middle East: A Documentary Record: 1914-1956, Vol. II, New York, 1972, p. 229. 
Therefore, Soviet strategy in support of its policy to control Gulf oil is indirect in approach.

There is no divergence in the regional and Paksitani thinking regarding the Soviet objectives and their approach. Although in the West, most defence analysts believe in Soviet plans to advance through Iran, from the Soviet viewpoint the Afghanistan-Baluchistan area offers many obvious politico-strategic advantages. Not many analysts have discussed the potential of an advance through Baluchistan in the Soviet strategy. Strategically, by their presence in Afghanistan, the Soviets have not only crossed the mountain barriers of the Elburz and the Hindukush ranges but have already outflanked the heartlands of both Iran and Pakistan and gained their vulnerable flanks. It also places them just about 350 miles from the strategic Straits of Hormuz. Politically too, an advance through Pakistan is not likely to draw a strong Western response. If this thesis has some validity, then perhaps writes Professor Scott Thompson and I quote "the Soviets would conclude that it was less dangerous - and in some ways more promising - to move south by way of Baluchistan. ${ }^{8}$ unquote

\section{The Regional Responses}

The regional response to lessen the severity of the threats is to create disincentives for a direct Soviet action by remaining members of the Non-aligned Movement, by refusing to grant bases to the United States and thus keeping the region free of superpower rivalry. Pakistan shares the stand of the other regional states that the security of the Gulf is the responsibility of the Gulf states.

Disincentives can, to a limited degree, minimize insecurity but are not a substitute for a set of active measures needed to enhance security against as complex a threat as the region is confronted with.

As part of active security measures, Pakistan and the Gulf states initiated various stpes to enhance the defence potential of the regional states and thus to substantially raise the level of deterrence against any possible aggression. Measures included the purchase of defence equipment by the individual states as well as conclusion of mutual agreements to enhance their effectiveness.

Pakistan has provided training personnel and facilities for the defense forces of almost all the Gulf states. Since the formation of the Gulf Cooperation Council (GCC) Saudi Arabia has assumed the major role of coordinating the foreign and defense policies of the Arabian Peninsular states (except South Yemen). Pakistan and Saudi Arabia have three agreements in the defense and security field. The first was signed in 1967, under which Pakistani personnel were to oversee the development of Saudi army and air force. ${ }^{9}$

8 W. Scott Thompson, "The Persian Gulf and the Correlation of Forces," International Security, Vol. 7, No. 1, Summer 1982.

9 Shirin Taher-kheli, The United States and Pakistan, Praeger, New York, 1982, p. 37. 
The other agreement, signed in 1983 provides for the exchange of information and training of security personnel in Pakistan or by Pakistan in Saudi Arabia. The third agreement calling for the extradition of criminals is similar to those signed by Saudi Arabia and all Arab Gulf states (except Kuwait). This agreement incorporates a clause, called the right of hot pursuit, which authorizes the security forces of one country to operate deep into the territory of the other to chase its criminals. ${ }^{11}$ Pakistan is the only non-Arab country with whom Saudi Arabia has signed such an agreement. These measures indicate existence of a perception of a common threat as well as a common response to it.

\section{Pakistan and Iran}

Pak-Iran relations right from Pakistan's founding to 1979 had remained very cordial and friendly and both shared a common perception of the major international and regional issues. The depth of their relations resulted in formal ties which linked Pakistan with Iran and Turkey in the Central Treaty Organization (CENTO) and the Regional Cooperation for Development (RCD). In the aftermath of the Iranian revolution, CENTO was formally terminated in 1979 but RCD is still intact.

A friendly Iran was a source of strength and support both for Pakistan and the Arabian Peninsular states. With the sudden collapse of monarchy in Iran in 1979 , the security of the region was adversely affected. The power on which the regional states could count for assistance in times of crisis, as had been evident in the 1965 and 1971 Indo-Pakistan wars, Dhoffari insurgency, and Iraq's threat to Kuwait's sovereignty, was no longer available. In this context, the question is not one of a threat from the revolutionary regime in Iran as much as the loss of a reliable and positive component of regional security which caused anxiety to Pakistan.

After the revolution, the government in Tehran not only differed with Islamabad's perspective on most international issues, but the Iranian leaders (including Ayatullah Khomeini) used as strong a rhetoric against Pakistan as they did against the other regional states and termed Pakistan a stooge of the United States. Pakistan not only refused to be provoked but openly supported the Islamic revolution in Iran as it was in conformity with Pakistan's own process of Islamization. The credit for vastly improved relations between these two countries largely goes to Pakistan patient and mature diplomacy. There are now frequent consultations at the ministerial level and trade links have been restored. As an indicator, Pakistan's exports to Iran have jumped from a mere about $\$ 3.4$ million (45 million rupees) in 1981 to about $\$ 38$ million in 1983

1 Ibid., May 27, 1980. 
(500 million rupees) - almost an eleven fold increase. Pakistan's imports from Iran increased from about $\$ 7$ million (95 million rupees) 1979 to about $\$ 50$ million (679 rupees) in 1982-83.12 In 1983/84, Pakistan became one of the major trading partners of Iran. In the recent past the Iranian suggestion to revive the nearly-dormant $\mathrm{RCD}$, in which Turkey is the third member, was a very welcome development from the regional perspective. Pakistan also does not subscribe to the view that Iran is a source of threat to the region and looks forward to an even greater cooperation with its western neighbor.

\section{Pakistan and The Iran-Iraq War}

Pakistan while expressing extreme distress and anguish over the war between two Muslim states, has kept a strictly neutral stance. In fact President Zia ul-Haq had undertaken the first mediation effort to bring an end to the war as chairman of the Organization of the Islamic Conference (OIC) and within the first nine months of the war made five peace attempts. Since then, Pakistan has continued to play an important and active role in seeking a negotiated solution to the war.

Several times during the 50-month old war, there were fears of grave escalation and even of superpower involvement. But, possibly, none came as close to a major international crisis as Iranian attacks during the spring of this year on commercial ships enroute to and from the ports of Kuwait and Saudi Arabia and its threat to close the Straits of Hormuz. Determination of the United States to keep the Straits open even if it involved use of force added the element of superpower involvement in an otherwise regional conflict. The Secuirty Council of the United Nations met urgently to consider the complaint of the Gulf Cooperation Council (GCC) states who wanted a strongly worded resolution condemning Iran as an aggressor. Pakistan was required to play a major behind-the-scene diplomatic role in hammering out a resolution which would be acceptable to the concerned parties and help ease out the crisis. After a comprehensive debate, the Security Council approved a resolution reaffirming the right of free navigation between ports of the countries not a party to the war. Iran rejected the resolution but acted in the spirit of it and helped in ending the crisis.

Some writers have suggested that Pakistan supplied arms to Iran in 1980/81 period. Apart from being factually inaccurate, such an act would have been against the government's declared policy of strict neutrality in the conflict. Iran's policy towards Pakistan during that period hardly had the benevolance for which Pakistan could rationally take such a partisan stand and risk alienating the Arab Gulf states. 
Pakistan's policy to the Iran-Iraq conflict has been and continues to stay neutral and to work for the termination of the hostilities and a negotiated resolution of the conflict.

\section{Pakistan and Southwest Asia: the 80s}

Traumatic events of the year 1979-the fall of the Shah followed by a fundamentalist revolution in Iran, take-over of the Grand Mosque in Mecca by radical fundamentalists, Soviet Military intervention in Afghanistan-and IranIraq War of 1980 brought about a qualitative change in the politico-strategic environment necessitating a fresh appraisal of Pakistan's regional role. Until late 1970s, threat perceptions of Pakistan and other regional states were divergent, but the turn of the decade of the 80 s saw a marked convergence in mutual threat perceptions. In fact the Southwest Asian subsystem has emerged as one strategic entity in which, apart from a common threat perception, internal destabilization in one part would also adversely affect the security calculus of the other.

Before 1979, ideology played a greater role in Pakistan's relations with the regional states, even though economic and security linkages were very well developed. Since then, the security dimension of the relationship has overshadowed the other two aspects, and that is a situation which promises to endure.

Failure to perceive Southwest Asia as one entity and considering that more important areas, like the Gulf, can be protected, while others can possibly be allowed to fall, would be a grave strategic miscalculation. Even if the Gulf is considered vital to the West it cannot be protected just in situ. The extent of the strategic frontiers needs to be recognized - which in fact has already been breached. Just to recall, Britain did not protect India by remaining in India; their strategic frontiers stretched as far as Tibet, Sin Kiang, Persia and Afghanistan. Pakistan in this context is not only a strategic frontier but a part of the region.

In the '80s, Pakistan has already signed two security related agreements, with Saudi Arabia and this security related cooperation is likely to continue and may even strengthen further.

\section{Conclusion}

Pakistan's relations with Southwest Asian states have had their ups and downs in spite of the much talked about bonds of ideology. However, it is not ideology which sustains state to state relations, but national interests. Convergence of important national interests, as is the case between Pakistan and the other regional states, leads to greater identification of their policies. In response 
to the changed geopolitical environment of the region the relations between Pakistan and Southwest Asian states have broadened and deepened and have given rise to an interdependency which is likely to endure in the forseeable future. 